\title{
On the Existential side of the Eternalism-Presentism Dispute
}

\author{
Francesco Orilia \\ Università di Macerata \\ Dipartimento di Studi Umanistici - Lingue, Mediazione, Storia, Lettere, Filosofia \\ Macerata \\ Italy \\ orilia@unimc.it
}

Article info

CDD: 100

Received: 01.10.2016; Accepted: 22.10.2016

DOI: http://dx.doi.org/10.1590/0100-6045.2016.V39N4.FO

Keywords:
Time
Existence
Past
Sentience
future

\begin{abstract}
The current analytical debate on time is full of attempts to adjudicate from a purely theoretical standpoint among competing temporal ontologies. Little attention has instead been devoted to the existential attitudes -- emotional or ethical -- that may lurk behind, or ensue from, the endorsement of one of them. Some interesting opinions have however been voiced regarding the two most prominent views in the arena, namely eternalism and presentism; it has been said that the former is nourished by a fear of death, or more generally by a desire of preservation for whatever we find precious and valuable, and that the latter is fuelled by a propensity to reap whatever fruits the present brings, as enshrined in the carpe diem motto. This paper explores such a territory by focusing on the reality of past sentience, whether joyful or painful, and on the open future. The first part contrasts the reality of past sentience that comes with eternalism with the denial of this reality that follows from presentism, and argues that from an emotional, or perhaps even moral, standpoint the latter is preferable to the former. The second part clarifies why the eternalist must renounce the open future, whereas presentism is consistent with it, and considers how its rejection or acceptance, as the case may be, could be emotionally, or even morally, significant for our conception of ourselves as free agents. The conclusion offers a tentative proposal regarding which temporal ontology is superior from an existential perspective and some ruminations on the impact that all this may have on the theoretical side of the issue.
\end{abstract}

Manuscrito - Rev. Int. Fil. Campinas, v. 39, n. 4, pp. 225- 254, out.-dez. 2016. 


\section{Introduction}

As I see it, the current ontological dispute about time, involving presentists, pastists, A-eternalists and B-eternalists as main contenders, ${ }^{1}$ is genuine and substantial. Those who think otherwise ${ }^{2}$ tend to reduce it to a merely verbal controversy. A natural outcome of this deflationary ${ }^{3}$ perspective is viewing the debate as animated at bottom by different emotional responses to temporal matters, which have no theoretical significance, but at best only a practical one. However, even though the deflationary perspective is ruled out, it may well be interesting to explore what we may call the existential side of the dispute and thus investigate whether emotional, ethical, perhaps ideological, attitudes or convictions may favor, or ensue from, the endorsement of a given temporal ontology or the rejection of another.

\footnotetext{
${ }^{1}$ According to presentism, only what is present exists or is real. In contrast, pastists also acknowledge the reality of the past and eternalists the reality of both past and future. A-eternalism and B-eternalism differ in that the former considers the distinction between past, present and future as objective, whereas the latter does not. Accordingly, from the perspective of B-eternalism, attribution of pastness, presentness and futurity should be understood in subjective terms, e.g., tokenreflexively by exploiting locutions such as "preceding the utterance of this token" or "simultaneous with the utterance of this token." The A-eternalit is similar to the presentist and the pastist in acknowledging the objectivity of the distinction between past, present and future and thus they are typically taken to be all supporters of a common approach, the so called A-theory. In contrast to it, Beternalism is often called $B$-theory. This way of classifying temporal ontologies reflects what is commonly found in the current analytic literature on time, but it should be noted that some may dispute it. For example, Oaklander would object to my generalized use of "eternalism," which applies to both A-theoretical and Btheoretical approaches (see Orilia 2014, note 7, and Oaklander 2014).

2 See, e.g., Lombard 2010.

${ }^{3}$ I owe this terminology to Ernesto Graziani, who adopts it its forthcoming doctoral dissertation.
}

Manuscrito - Rev. Int. Fil. Campinas, v. 39, n. 4, pp. 225- 254, out.-dez. 2016. 
Continental philosophers such as Bergson and Heidegger could perhaps be interpreted as being mainly concerned with this sort of inquiry, but even in thinkers of a completely different orientation, belonging to the tradition of scientific, or analytic, philosophy, we find some hints of it. Both Einstein and Russell have suggested that an eternalist perspective may be soothing and appeasing ${ }^{4}$ and Reichenbach (1956, Ch. 1) has argued that it may stem from our fear of death, ${ }^{5}$ or more generally, I would say, from a desire to see as preserved what we value most, not only ourselves and our dear ones, but also our significant deeds, or whatever valuable we humans have produced, perhaps even whatever seems marvellous in the universe. ${ }^{6}$ More recently, Dorato (1995, p. 41) has deemed "safe to assume" that a presentist" "should be a follower of the aesthetic way of living or a 'seducer' in Kierkegaard's sense," 8 someone who sees "the present ... as the only moment in which we can fully live and enjoy ourselves," and who "should be completely indifferent to the remote or nearer past and future, and worry only about whatever has immediate significance for the present: Carpe diem?'

It could be true that some eternalists derive emotional rewards from their credo, in the way suggested by Einstein, Russell and Reichenbach, and that some presentists are guided by the existential stance enshrined in

${ }^{4}$ Einstein famously tried to console his friend Michele Besso's wife for the loss of her husband by remarking that the distinction between past, present and future is a mere illusion (Einstein and Besso (1972, p. 537)), and Russell (1917, Ch. 2, §3) wrote that emancipation from this illusion is "both in thought and feeling ... the gate of wisdom."

5 Although Reichenbach does not speak explicitly of "eternalism," but rather of a view in which there is no real becoming and thus no real ceasing to be, I think it is most appropriate to interpret what he says as concerning eternalism in general, whether of the A or B variety.

${ }^{6}$ A similar attitude toward death and caducity is associated to his temporal ontology by the Italian philosopher Emanuele Severino (1958), who could, I think, be classified as an eternalist. It should be kept in mind, however, that I am using "eternalism" in line with the current analytic debate on time and Severino certainly does not belong to the analytic tradition.

${ }^{7}$ Dorato calls presentism "the instant view of reality."

${ }^{8}$ Dorato refers here to Kierkegaard's Either/Or.

Manuscrito - Rev. Int. Fil. Campinas, v. 39, n. 4, pp. 225-254, out.-dez. 2016. 
Kierkegaard's seducer, but I shall not press these points here. I would rather like to focus on the existential attitudes or reactions that one may have in response to two deep ontological divergences that divide presentism and eternalism.

The first divergence has to do with the existence of the past. According to the presentist, the past does not exist, it is not part of the ontological inventory. In contrast, for the eternalist, the past is as real as the present. As we saw, this may constitute a ground for a consolatory attitude regarding death and more generally the caducity of all that we cherish. But there is the other side of the coin; we know that the past is not only a container of gems that we wish could be preserved, but is also full of tremendous sorrow; physical and moral pain, injustice and evil of all sorts. When facing this, one may think, the presentist should be relieved by her belief that the past is not real and the eternalist, in contrast, should be dismayed by her belief in the existence of the past.

The second divergence regards the open future. Presentism can assume it, and so have in store the belief needed to provide a rational ground for another existential stance famously dramatized by Kierkegaard, when he points out, in The Concept of Anxiety, that the present is the vantage point wherefrom an array of genuine future possibilities are displayed for us to choose. This freedom can be exciting, but the choices before us can be of momentous importance, up to the point of being characterizable as choosing ourselves, as decisions regarding what we want to be; in Kierkegaard's theological language they can be a matter of settling for eternity on either salvation or damnation. Thus, freedom means also the angst arising from the burden of feeling responsible for one's actions. From the eternalist's viewpoint, on the other hand, the future is not open. With a belief of this sort Kierkegaardian anxiety is bereft of its raison d'être and this can be placatory, although the price for this may be some loss of the sense of dignity coming from a view of ourselves as selectors of genuine, not prefixed, options.

It seems to me that not enough attention has been paid so far to past sorrow in relation to the existential attitudes that might undergird a choice between presentism and eternalism. Moreover, the claim that eternalism cannot embrace an open future and free will has been questioned many times (see, e.g., Oaklander 1998), and my impression is that some 
clarifications are still needed to put it on more solid grounds and bring to light the existential aspects of the issue. Hence, what I would like to do in this paper is to dwell on these two issues as follows. First, in $\$ 2$, I shall argue that the eternalist's acknowledgement of the reality of past joy and sorrow is emotionally or even morally worse, from an existential point of view, we may say, than the presentist's denial of their existence. Next, in $\$ 3$, I shall try to further clarify the sense in which the eternalist, contrary to the presentist, gives up the open future and, consequently, free will, and then focus on how this may be existentially significant. I shall then draw some tentative conclusions on how existential issues can be connected to the choice of either presentism or eternalism.

Some words of clarification on two points are in order before I go ahead. First point. I here use "existential" in a sweeping sense to encompass the emotional and moral aspects of our lives, which, some may say, are imbued with ideological preconceptions due to our economic, social, cultural and historical condition. However, I shall set aside worries about the role of any such preconceptions in shaping our existential stance, and rather make an effort to distinguish in it the subjective side of our emotional responses and the (ideally) more objective or at least intersubjective side of our moral perspective. Second point. I have simplified matters by focusing on presentism and eternalism, and, as a result, pastism is sacrificed; as regards the topics of $\$ 2$, it would have been possible to contrast, in a more general fashion, on the one side presentism and, on the other side, in one fell swoop, pastism and eternalism; 9 and, concerning the issues of $\$ 3$, pastism could have been put on one side of the trench, together with presentism, with eternalism on the other side. However, this neglect of pastism makes for a faster exposition and what I have just said can be easily taken into account by the reader. Moreover, I have also concentrated on eternalism tout court, without caring to distinguish, for the most part, between its A and B versions (see, however, $\int 2.3$ ). But it should be clear in what follows that this distinction is not relevant for the topics discussed here, since what really matters is that both forms of eternalism acknowledge, though in different ways, the reality of past and future. Similarly, it is not relevant here the distinction that one finds in the literature between two forms of pastism, the

${ }^{9}$ As I do in Orilia 2015.

Manuscrito - Rev. Int. Fil. Campinas, v. 39, n. 4, pp. 225-254, out.-dez. 2016. 
growing block and the ramified future views. This is not to deny, of course, that other existential issues, which I do not consider here, may require separate considerations of the different kinds of eternalism and pastism, or of other sorts of temporal ontologies.

\section{Past sentience}

We shall concentrate in this section on past joy and sorrow from the perspective of both eternalism and presentism. More precisely, we shall focus on joyful and sorrowful events, say your first kiss to your beloved one or a painful visit to the dentist. Obviously, such events involve sentient beings. The focus thus is, we may say, on past sentience. As we shall now see, depending on whether we contemplate joyful or sorrowful sentience, we may be existentially inclined toward either eternalism or presentism. After noting this, I shall try to adjudicate among these contrasting inclinations and then consider and rebut two objections to my verdict.

\subsection{Two contrasting arguments}

Fortunately, there have been, there are, and presumably there will be hosts of joyful events, and the desire to think of them as part of reality is quite understandable from an emotional point of view. We could perhaps even say that there is a moral preference in favor of their being part of reality, on account of the fact that, from a broadly moral point of view, the occurrence of joy is ceteris paribus morally more valuable than the absence of joy, since ceteris paribus it seems morally preferable to act as far as possible in such a way as to bring about joy in ourselves and the world surrounding us. ${ }^{10} \mathrm{Be}$ this as it may, we can at least say that the occurrence in reality of joyful events is existentially preferable to their absence. Since eternalism grants the existence of all past events, and thus in particular of all joyful events, whereas presentism denies their existence, it seems we could

\footnotetext{
${ }^{10}$ One could object here that joy may be morally outrageous if it is a reaction to sorrowful events such as the suffering of an innocent person. In response to this, for the sake of the argument I wish to develop here, we can assume that such reactions are not included among the joyful events.
}

Manuscrito - Rev. Int. Fil. Campinas, v. 39, n. 4, pp. 225- 254, out.-dez. 2016. 
conclude that an eternalist world, as we may put it, is existentially preferable to a presentist world. In sum, we can construct an argument that may be seen as underlying the pro-eternalist existential attitude on which Reichenbach invited us to focus. We may call it the pro-eternalist preservation argument. Here it is in a streamlined fashion:

(E1) Occurrence of joy is existentially preferable to absence of joy.

(E2) If there were past joyful events, then: (i) they are part of reality, if the world is eternalist; (ii) they are not, if the world is presentist.

(E3) There were joyful events.

Hence,

(EC) An eternalist world is existentially preferable to a presentist world.

Convincing as this may be, there is however the other side of the coin, namely sorrowful events, which goes perhaps neglected or underestimated by anyone who is existentially driven to eternalism for the reasons suggested by Reichenbach. If all past events exist, if they are part of reality, as they are in an eternalist world, then a fortiori, all past sorrowful events are part of reality. In contrast, in a presentist world, no past events are part of reality and hence, a fortiori, no past sorrowful events are part of reality. Moreover, just as one can claim that occurrence of joy is morally, or at least emotionally, better than absence of joy, one can also urge that absence of sorrow is morally, or at least emotionally, better than occurrence of sorrow. ${ }^{11}$ Unfortunately, as we all know very well, there were, and there are, dreadfully many sorrowful events, going from relatively minor ones

11 There is of course sorrow, in particular physical pain, that it is necessary to undergo for the sake of a future advantage, as when one accepts to undergo surgery to cure a disease. This sorrow is not of course morally objectionable and may, be more bearable than other sorts of sorrow. But qua sorrow is, we should admit, in itself, morally, or at least existentially, undesirable; it would be better if the advantage could be reached without it.

Manuscrito - Rev. Int. Fil. Campinas, v. 39, n. 4, pp. 225-254, out.-dez. 2016. 
such as headaches and toothaches to those of gigantic magnitudes such as those involved in devastating earthquakes, wars or genocides. In sum, just as we constructed a pro-eternalist preservation argument, we can similarly construct an analogous, but opposite, pro-presentist annibilation argument.

(P1) Absence of sorrow is existentially preferable to occurrence of sorrow.

(P2) If there were past sorrowful events, then: (i) they are part of reality, if the world is eternalist; (ii) they are not, if the world is presentist.

(P3) There were sorrowful events.

Hence,

(PC) a presentist world is existentially preferable to an eternalist world.

Just as the pro-eternalist argument is based on an axiological principle, (E1), the pro-presentist argument is based on another axiological principle, (P1), which appears to be at first glance at least as good as (E1). We thus have, we may say, an argument in favor of the existential preferability of eternalism and a symmetric argument in favor of the existential preferability of presentism. Is there a way to choose?

An utilitarian might urge that, in order to adjudicate the dispute, we should calculate the amounts of past (and future) joy and sorrow in order to see whether sorrow prevails over joy or vice versa. But such a computation is of course hardly possible and, besides, the utilitarian viewpoint that motivates it might be questioned from other ethical perspectives. Nevertheless, independently, or even in spite, of this sort of computation, it seems to me that the pro-presentist argument sticks out. For, setting aside sadistic inclinations that a minority of us could have, the reality of sorrow that comes with eternalism seems so intrinsically horrifying that it cannot be compensated by any reality of joy. To put it otherwise, whatever comfort we may gain from the thought that joyful past events exist sub specie aeternitatis, this can hardly balance the dismay for the analogous existence of the sorrowful ones: the dismay prevails, even if in the past there had been overall, let us imagine, more joy than sorrow.

Manuscrito - Rev. Int. Fil. Campinas, v. 39, n. 4, pp. 225-254, out.dez. 2016. 
I think we can bring home this point by an analogical reasoning. Imagine that a powerful and eccentric demon will flip a coin with this intention: if the outcome is cross, he will bring about that a number of people will enjoy an extraordinarily pleasant experience and that someone will suffer excruciating pain; if the outcome is head, he will do nothing. Perhaps a utilitarian could insist that, if the quantity of pleasure brought about by the pleasant experiences is sufficiently high, the world is better off with them, despite the simultaneous existence of the pain. But this seems cruel and thus presumably most of us would hope that the outcome is head: it is preferable not to have an unfortunate fellow in excruciating pain, even though nobody will enjoy the extraordinarily pleasant experience. Analogously, we should seemingly prefer a world in which all past sorrowful events are no part of reality, even if this means that all past joyful events are similarly erased. This seems convincing enough to me, but there are two objections that is worth considering and that might shed further light on this issue. I call them the ugly truthmakers objection and the ugly history objection. Let us deal with them in turn.

\subsection{The ugly truthmakers objection}

As is well-known, there is a truthmaker problem for presentism. It arises once the presentist accepts the plausible truthmaker principle, according to which (at least some) truths require truhmakers. In particular, true pasttensed propositions such as the propositions that Caesar crossed the Rubicon require truthmakers. Pastists and eternalists can appeal to past events to provide them, but obviously the presentist cannot do the same and must rather find in her ontological inventory alternative items that can go proxy for past events. There is no problem of course if one rejects the truthmaker principle (Merricks 2007) or denies that past-tensed propositions are ever really true. But these moves are not popular and accordingly many presentists have proposed proxies of past events of different sorts. For example, Bigelow's Lucretianism (1996) appeals to "propositional" properties (e.g., being such that Caesar crossed the Rubicon), which the world as a whole exemplifies. Keller's heacceitism (2004) appeals to present haecceities of

Manuscrito - Rev. Int. Fil. Campinas, v. 39, n. 4, pp. 225- 254, out.-dez. 2016. 
past objects and times; Bourne's (2006) and Crisp's (2007) Ersatzism appeal to a precedence relation linking Ersatz times. ${ }^{12}$

The ugly truthmakers objection ${ }^{13}$ exploits the inclusion of such truthmakers in the presentist's ontological inventory: if they exist, there are among them the "ugly" ones that make true, now, past-tensed propositions such as the proposition that there was the Holocaust and more specific Holocaust propositions such as that Ann Frank was murdered; and, thus goes the objection, they make the world a morally ugly world, and thus, we may add, an existentially uncomfortable world; just as sorrowful past events render ugly and uncomfortable the eternalist world. Suppose for example that Lucretianism is right and accordingly the world has now the property of being such that Ann Frank was murdered. According to the objection that we are considering, such a world is not existentially better than an eternalist world in which the event of the assassination of Ann Frank precedes present events such as my writing these words. The idea is that the ugliness of the presentist world is witnessed by its exemplifying the propositional property of being such that Ann Frank was murdered no less than by its including, if eternalism is true, the event of the assassination of Ann Frank. No improvement, the objection continues, is offered by the other solutions that the presentist can offer in responding to the truhmaker problem. For instance, if haecceitism is true, Ann Frank's haecceity is appropriately related to the property of being murdered and to the haecceity of the time of the murder in question, in a way sufficient to make it true that Ann Frank was murdered. And this and other truthmakers of this sort are enough to certify the ugliness of the presentist world. Independently of which sort of truthmakers the presentist will choose, the objection concludes, analogous considerations will be in play.

I do not think that this objection has any real bite in the end, but it is instructive to see why. The point is that, no matter how close the presentists' truthmakers are to the eternalist's past events, only the latter can involve sentience and thus real suffering. Metaphorically speaking, the truthmakers of true past-tensed propositions, whatever they are, can be compared to films shot when certain events were taking place. When the

\footnotetext{
12 See Orilia 2016 for my own proposal.

${ }^{13}$ I owe it to Gregory Landini.
}

Manuscrito - Rev. Int. Fil. Campinas, v. 39, n. 4, pp. 225-254, out.-dez. 2016. 
events are gone, the films remain. If the events were unpleasant, they involved suffering; but no suffering is involved in the corresponding films. If a torturing event is filmed, the film can certainly testify that the victim was in pain and those who watch the film may have an empathic sorrowful response to it. But this response is not the victim's pain. If presentism is right, fortunately this pain is no longer around. In contrast, if eternalism wins the day, the pain is with us in the ontological inventory. True, if presentism wins, we still have the film, whereas, given eternalism, there is no such film, or at least no need to suppose that there is. But certainly it is better to have the film of the torture than the real torture, for only the latter involves the victim's pain. In sum, this objection does not really undermine the pro-presentist argument.

\subsection{The ugly history objection}

This other objection ${ }^{14}$ is related to the previous one in that it also presupposes that the presentist acknowledges the truth of sad past-tensed propositions such as the one asserting that Ann Frank was murdered. But it differs inasmuch as it questions the assumption that the existential (emotional or even moral) value of a world is based fundamentally on what is real or existent in that world. The suggestion is that the value of a world depends equally on what exists and on what existed, i.e., we may say, on its history, regardless of whether this history is understood in a presentist or eternalist fashion; so that there is no difference in terms of existential value between a presentist world in which the Holocaust existed and no longer exists and an eternalist world in which the Holocaust is part of reality: both are equally bad insofar as they have a morally ugly history, and thus we should have no preference to be in one rather than the other. A presentist friend, Tomis Kapitan, put the matter as follows in an email exchange: "I tend to be a presentist, but take utterly no comfort in it. I don't think that a presentist world is 'better' in any sense. Even if I agree that past sufferings are no longer real, they were real, and that's bad enough to cause me considerable anguish. I don't think that reality would be any worse off if

${ }_{14}$ An anonymous referee raised this issue by elaborating on the truthmaker objection.

Manuscrito - Rev. Int. Fil. Campinas, v. 39, n. 4, pp. 225- 254, out.-dez. 2016. 
eternalism were true. Similarly, past enjoyments are no longer in existence, and sometimes I get delight in reflecting upon them, but I don't think that the world would be any better if reality is a four-dimensional universe."

I would like to say in reply that here is an element of truth in all this, but once this element is disentangled from the rest, the objection collapses. One can and should concede that what happened in the past is relevant for the existential evaluation of a world. Thus, for example, a world in which the Holocaust existed is existentially far less desirable than a world in which there was no Holocaust. Yet, in a presentist perspective, the fact that certain events were real cannot have the same relevance in the evaluation as the fact that certain other events are real. For example, it is bad now that an innocent victim was tortured in a concentration camp and thinking of this can horrify us now. Yet, the reality of someone's being tortured now, with the excruciating pain of the victim going on now, is worse. In contrast, in an eternalist perspective, this can hardly be claimed. To see this, it is useful to focus on the analogy between time and space that is often brought up in clarifying what B-type eternalism amounts to. In the latter perspective, the difference between past, present and future is compared to the subjective distinction between far and near: we are distant in a temporal sense from a torture going on in Auschwitz just as we are far in a spatial sense from a distant planet; and just as the distant planet is as real as the Moon near us, similarly the past torture in Auschwitz is as real as a present torture going on now. But, if this is so, the past torture is as bad as the present one, just as a torture is bad whether it takes place on the far away planet or on the nearby Moon. ${ }^{15}$

The picture changes in A-eternalism. For, according to it, an objective pastness accrues to past events, and this makes them not fully comparable to spatially distant objects. Yet, it does not really matter for our purposes,

\footnotetext{
${ }^{15}$ This is not to say of course that the B-theorist regards spatial distance as the same as temporal distance; the point is simply that for the B-theorist earlier events are real just like spatially distant events. And this point remains no matter how much the B-theorist emphasizes the difference between spatial and temporal relations, e.g. in the way put forward by Oaklander (2015) in his recent defense of a Russellian version of the B-theory, called "R-theory," according to which temporal precedence is a primitive unanalyzable external relation.
}

Manuscrito - Rev. Int. Fil. Campinas, v. 39, n. 4, pp. 225- 254, out.dez. 2016. 
unless this pastness makes events somehow less real, to the point that past sorrowful and joyful events do not involve sentience. If so, however, Aeternalism becomes rather questionable, for it almost seems to embrace contradictiones ex vi terminorum. Here is how Zimmerman (2008, p. 215) makes this point:

... if past headaches are to be much better than present ones, these Atheorists must say things like: a headache is only truly painful when it is present; yesterday's headache, although it exists, is no longer painful ... and that's why it no longer concerns us. ... Although this view makes sense of our relief when pain is past ... it has less appealing consequences as well. Headaches can exist but not be truly painful.

It is better to assume, in sum, that A-eternalists are not committed to past pains that do not hurt et similia. But then they are for present purposes in the same boat as the B-eternalists. From the point of view of both of them, past sorrow should have the same negative existential weight as present sorrow. In contrast, in the presentist perspective, one can say that a world in which there was pain is worse than a world in which there was no pain, while admitting that present pain is altogether another matter.

Despite the above rejoinder, it has been suggested to me ${ }^{16}$ that an appropriate mental experiment could provide new fuel for the ugly history objection. Here is how. So far we have compared, so to speak, our presentist world and our eternalist world, that is, two worlds both of which have our actual history, a history that unfortunately includes the Holocaust and many other evils. But we may also compare our eternalist world to a presentist counterfactual world whose history differs from our actual history only because it includes some additional sorrow, due, say, to a longer duration of World War II, sufficient for the Nazi to bring to completion their genocidal programs. What is existentially preferable, our eternalist world or the presentist counterfactual world? The supporter of the ugly history objection may want to suggest here that the former is better, despite the enormous amount of sorrow that is cut from reality in the latter alternative. Suppose this answer were correct. This seems to back up the intuition that triggers

${ }^{16}$ Thanks to Ernesto Graziani for pressing this point.

Manuscrito - Rev. Int. Fil. Campinas, v. 39, n. 4, pp. 225-254, out.-dez. 2016. 
the ugly history objection. The additional past sorrow brought about by a longer World War II, devastating as it might have been, is very small, when compared to all the past sorrow that is part of reality in our eternalist world. If, in spite of this, our eternalist world is better than the counterfactual presentist world, this may be taken to suggest that the existential value of a world depends so much on its history that metaphysical considerations regarding the presentist or eternalist nature of this history can do little to change the picture.

I do not think, however, that this conclusion follows, even if we concede the existential superiority of our eternalist world over the counterfactual presentist world under consideration. Perhaps, the history of a world matters to a very large extent, an extent larger than we might have thought before this thought experiment; and it is certainly worth investigating why this is so, or at least why it seems to us that it is so. Nevertheless, this does not yet prove that the way in which metaphysically this history should be considered is irrelevant. It remains true that in an eternalist world a past sorrow is as real as a present sorrow in a distant planet and that accordingly our presentist world is better than our eternalist world. Perhaps the latter fares better with respect to other presentist worlds, but after all we are interested in our presentist world.

\section{The Open Future and Libertarian Free Will}

Let us turn now to the second issue on the agenda. I shall first make a proposal regarding how the open future is best characterized and then explain why eternalism is not compatible with it, whereas presentism is. I shall then move on to consider free will, arguing that the incompatibility of eternalism with the open future generates an incompatibility with a libertarian conception of free will, and then suggest that all this may have an impact on the existential evaluation of presentism and eternalism.

\subsection{Open versus Prefixed Future}

With a since long fashionable terminology (see, e.g., Gale 1968, Sect. III), the future is open, we are told, or perhaps it is not, and it is thus, we may

Manuscrito - Rev. Int. Fil. Campinas, v. 39, n. 4, pp. 225- 254, out.-dez. 2016. 
say, unopen or closed. Let us use the word "closed," however, cum grano salis, since it is typically reserved for the past, and we should not take for granted that considering the future as not open amounts to viewing it as close in the very same sense in which the past is to be regarded as closed. Some rather speak, instead of a closed future, of a predetermined, prefixed, or simply fixed future. I would avoid "predetermined" and related words, since they are remindful of the traditional doctrine of (causal) determinism, which, as we shall see, cannot be identified with the thesis that the future is not open. "Fixed" or "prefixed" are then better terms, but I shall prefer "prefixed" (and related words), since the prefix "pre-" appropriately reminds us that there is openness of the future, or lack thereof, as the case may be, from the perspective of a preceding moment, the present one in particular. But how should the openness of the future, and correspondingly its prefixation or closedness, be characterized?

One way of seeing the matter is in purely epistemological terms: the future is open because we simply do not know, for the most part, what lies ahead of us; for example, we do not know, to take the classical example, whether or not there will be a sea battle tomorrow, or whether at some later time a certain asteroid will impact the moon. This is not satisfactory, however, since the intuitive distinction between an open and a closed future that we want to capture here appears to be independent from what we happen to know; whether the future is open or not seems to be an objective matter, not grounded on the existence of knowing agents; the asteroid may or may not turn out to impact the moon, but this is not grounded on what we know about it.

Alternatively, the openness of the future has been characterized in terms of our capability of bringing about, as agents, certain events, or, as it is sometimes put, our ability to control to some extent the future; if it is up to me, for example, whether the event of my standing up will, or will not, occur in five minutes, or, if it is up to you that you will be sitting in ten minutes, the future appears to be open to a certain extent. On the other hand, if no events are up to us, under our control, then the future is closed. But again this links the open/closed distinction to the existence of agents, in this case agents with a capacity for action, and one could insist once more that the distinction in question is not founded on the existence of agents, let alone acting agents. As we shall see, there is a relationship between

Manuscrito - Rev. Int. Fil. Campinas, v. 39, n. 4, pp. 225- 254, out.-dez. 2016. 
prefixation and what we can do, but this should not lead us to ground the openness/prefixation distinction on that.

A way of avoiding the recourse to agents is to appeal to the truth values of future contingent propositions, such as the famous proposition that there will be a sea battle tomorrow (see, e.g., Diekemper, 2007, sect. I, part B). The future is open, one could say, if, for at least some such propositions, neither they, nor their negations, are true now; perhaps they have a third truth value, Indeterminate, different from truth and falsehood, as famously proposed by Lukasiewicz, or perhaps they lack a truth value altogether, as in Van Fraassen's (1966) supervaluationist approach. Here we have the idea of characterizing the openness of the future in terms of truth, or lack thereof, at the present time, of tensed propositions regarding the future, such as the proposition that tomorrow there will be a sea battle. I think that resorting to the truth of propositions goes in the right direction, but we must proceed with care on various fronts.

First of all, on the one hand, the appeal to tensed propositions may be opposed by some B-theorists; and, on the other hand, A-theorists may dislike a tenseless way of speaking. Moreover, it could be better (especially in view of discussing willed actions) to focus, not on tomorrows, but on precise moments of time, those that can be singled out by a very specific date such as "noon on April 1, 2038;" however, presentists who think that there are no past or future times may object to taking these dates at face value. I thus propose that we consider, with a proviso to be seen in a moment, dated tenseless sentences, which officially express dated tenseless propositions, such as the proposition that at noon on April 1, 2038, there is a sea battle (it will be convenient to speak, in an obvious way, of the time or date, of such propositions; in the example that we have just seen the time of the proposition is noon on April 1, 2038). A sentence such as "at noon on April 1, 2038, there is a sea battle" (and the corresponding proposition) can be taken to regard the future, because noon on April 1, 2038 is a future time. ${ }^{17}$ And now we come to the promised proviso: we should allow A-

${ }^{17}$ In line with what already said in note 1 , here and elsewhere in this paper, a Btheorist can understand "future time" in tenseless terms as meaning, e.g., something like "time later than the time at which this token is uttered." And of course "past time," "present time" or "now" can be understood in a similar fashion.

Manuscrito - Rev. Int. Fil. Campinas, v. 39, n. 4, pp. 225-254, out.-dez. 2016. 
theorists, and in particular presentists who refuse to acknowledge future (and past) times, to interpret these sentences in a tensed way; so that, for instance, a sentence such as "at noon on April 1, 2038, there is a sea battle" be taken to express the tensed proposition that in $n$ units of times there will be a sea battle (with an appropriate choice of $n$ and of the unit of measurement, depending on the time of utterance). Nothing substantial in the following discussion will depend, I think, on these choices.

Next, for generality's sake, I propose that we extend talk of propositions' being true at the present time to talk of propositions being true at a given time, so that we can consider whether a dated proposition, e.g., that at noon on April 1, 2038, there is a sea battle, is true at a time, say 3:30 p.m. on April 12,2037 , that precedes the time of the proposition in question; which in turn means, we should admit, entertaining the further (more complex) proposition that it is the case (already) at 3:30 p.m. on April 12, 2037 that at noon on April 1, 2038, there is a sea battle.

Furthermore, and most importantly, however, I do not think that it is necessary to invoke a third truth value or truth-value gaps, nor for that matter additional complications such as distinctions between truth and determinate truth, or settledness and unsettledness of truth values. ${ }^{18}$ It is however very important in this context to be clear about scope when we need speak of the negation of a certain proposition. For example, in dealing with the negation of the proposition that at noon on April 1, 2038, there is a sea battle, are we considering that it is not the case, now, that at noon on April 1, 2038, there is a sea battle, or are we rather considering that that at noon on April 1, 2038, there is no sea battle? In other words, is the negation external or internal with respect to the date of the proposition? To avoid misunderstandings, a tiny bit of formalization can be useful.

${ }^{18}$ Barnes and Cameron $(2009,2011)$ have recently analysed the open future by relying on a primitive notion of metaphysical indeterminacy and proposing that a certain proposition $\mathrm{P}$ may have a truth vale, truth or falsehood, with no third option allowed, and yet not have it determinately, so that it is unsettled which truth value, whether truth or falsehood, P has. I find it hard to make sense of the idea that a truth value is possessed and yet is unsettled, but even if this can be coherently defended, it seems to me that a characterization of the open future that avoids these theoretical complications is preferable.

Manuscrito - Rev. Int. Fil. Campinas, v. 39, n. 4, pp. 225-254, out.-dez. 2016. 
Let us assume that there are undated atomic propositions that describe the occurrence of a certain event, propositions such as that Barak Obama is sitting, or that Obama is kissing Michelle, or that the moon is at a certain position relative to the earth. For present purposes, we might even consider as undated and atomic the classical example of the proposition stating that there is a sea battle. Assume further that there are also undated molecular propositions of various complexity obtained from undated atomic propositions by means of logical operators, so that in particular there are negations of undated propositions, which we shall represent as $\sim \mathrm{P}$, where $\mathrm{P}$ is a proposition; if $\mathrm{P}$ is atomic, $\sim \mathrm{P}$ is, we shall say, a negated atomic undated proposition. The proposition that we entertain when we consider whether an undated proposition, $\mathrm{P}$, is true at a time, $\mathrm{t}$, can be conveniently represented as follows: @(t, P); P may be called the internal proposition of $@(t, P)$ and $t$, in line with what we said above, the time (or date) of @ $(\mathrm{t}, \mathrm{P})$. For example, if $\mathrm{P}$ is the proposition that there is a sea battle and $\mathrm{t}$ is noon on April 1, 2038, then @(t, P) is the proposition that at noon on April 1, 2038, there is a sea battle; and, with obvious terminology, we can add that $\sim(t, P)$ and @(t, P) are the external and the internal negations of @ $(\mathrm{t}, \mathrm{P})$, respectively. As already noted, propositions of this sort are dated propositions, and, we can add, if their time is a future time, they are also future-dated propositions. We can further enrich this notation in a natural way so as to also conveniently represent propositions asserting that dated propositions are already true at a certain preceding time. Propositions of this sort can in fact be taken to have the form @ $\left(t^{\prime}, @(t, P)\right)$. For example, if $t^{\prime}$ is 3:30 p.m. on April 12, 2037, $\mathrm{t}$ is noon on April 1, 2038, and $\mathrm{P}$ is the proposition that there is a sea battle, then@( $\left.\mathrm{t}^{\prime}, @(\mathrm{t}, \mathrm{P})\right)$ is the proposition that it is true at 3:30 p.m. on April 12, 2037 that at noon on April 1, 2038, there is a sea battle.

Armed with this, we can now add that a prefixed proposition is a true dated proposition such that it is true at a time prior to the date of the proposition in question that the proposition is true at the prior time in question; more precisely, the prefixed proposition in question can be said to be prefixed at the prior time in question. In other words, a proposition prefixed at time $t^{\prime}$ is a true proposition of the form @ $(t, P)$ such that $t^{\prime}$ 
precedes $\mathrm{t}$ and the proposition @ $\left(\mathrm{t}^{\prime}, @(\mathrm{t}, \mathrm{P})\right)$ is also true. ${ }^{19}$ Thus, for example, it is prefixed now, at time $t^{*}$, that there will be a sea battle tomorrow, at time $\mathrm{t}$, if the following proposition is true: @ $\left(\mathrm{t}^{*}, @(\mathrm{t}\right.$, there is a sea battle)). We can then define the thesis of the open future as the claim that, for at least some future-dated proposition @ $(t, P)$, where $\mathrm{P}$ is atomic and undated, neither@(t, P), nor its internal negation@ @ $(t, \sim P)$, is prefixed. More specifically, we can say that a future time $t$ is open, from the point of view of a preceding time $t^{\prime}$, with respect to whether $\mathrm{P}$ or not $\mathrm{P}$, just in case neither@(t, P), nor @ $(\mathrm{t}, \sim \mathrm{P})$, is prefixed at $\mathrm{t}^{\prime}$; in other words, just in case neither@(t',@(t, P)),nor@(t'@(t, P).

\subsection{Prefixation and Necessity}

It seems intuitively clear that prefixation is a sort of necessity: if it is now true that there is a sea battle at noon on April 1, 2038, one seems bound to say that, when noon on April 1, 2038 finally arrives, a sea battle must occur then. But can we somehow clarify this intuition? And how can it be the case that there is prefixation? These two questions are interrelated, because we can somehow elucidate what necessity as prefixation is by at least sharply distinguishing it from other sorts of necessities; and, by focusing on these other sorts of necessity, we can see ways in which prefixation is brought about.

We commonly recognize logico-mathematical, metaphysical, and nomic sorts of necessity, on which bases most, or at least some, of us would claim, e.g., that $2+4=4$ is necessary in a logico-mathematical sense, that Clinton is necessarily human in a metaphysical sense, and finally that it is necessary in a nomic sense that there will be a total solar eclipse visible in North America on August 21, 2017 (see http://eclipse.gsfc.nasa.gov/solar.html; consulted on October 28, 2016). These sorts of necessities may go hand in hand with necessity as prefixation, perhaps even ground it. When we say that it is

\footnotetext{
${ }^{19}$ It may be worth noting, incidentally, that a true proposition @ $(\mathrm{t}, \mathrm{P})$ prefixed at t' should also be taken to be prefixed at any time in between t' and $t$. To illustrate, if it is now true that tomorrow, at time $t$, there will be a sea battle, then the dated proposition asserting that at $\mathrm{t}$ there is a sea battle is prefixed now and then presumably at any time in between now and $t$.
}

Manuscrito - Rev. Int. Fil. Campinas, v. 39, n. 4, pp. 225-254, out.-dez. 2016. 
nomically necessary that there will be a total solar eclipse visible in North America on August 21, 2017, we mean that the laws of nature and the present state of the world jointly necessitate the occurrence of such an eclipse on that date. Now, if there is such a necessitation, springing, so to speak, from the present moment (which is not to say of course that this necessitation cannot be further traced back), then the dated proposition that on August 21, 2017, there is a total solar eclipse visible in North America is true at the present moment and thus is prefixed. But it is prefixed because it is nomically necessary. Similarly, suppose we can take for granted, perhaps because of nomic necessity, that Clinton will be alive on August 21, 2017, and that, from the point of view of metaphysical necessity Clinton cannot fail to be human; if so, we may want to say that it is prefixed now that on August 21, 2017 Clinton will be human and in this case metaphysical necessity (with support from nomic necessity) grounds necessity as prefixation. Finally, suppose we grant (although many of us would want to deny this) that logico-mathematical truths are not atemporal truths, but truths at all times, i.e. eternal, or, as some prefer to say, sempiternal truths. Then, of course, it is true and also prefixed that on August 21, 2017, 2+2=4, since, e.g., it is already true now that on August 21, 2017, 2+2=4. In this case, necessity as prefixation is grounded on logico-mathematical necessity.

Clearly, if determinism is true, then there is a generalized prefixation due to nomic necessity. In other words, if there is determinism, the future is not open. According to determinism, the laws of nature and the state of the universe at any given time jointly necessitate the state of the world at any subsequent time and thus in particular whether at that subsequent time a certain specific event will, or will not, occur. Thus, in particular, for any undated atomic P,@(t, P) or @(t, P) is prefixed now; in other words, either@(t',@(t, P)) or @ ( $\mathrm{t}^{\prime} @(\mathrm{t}, \sim \mathrm{P})$, where $\mathrm{t}^{\prime}$ is the present time.20

\footnotetext{
${ }^{20}$ With our notation we can specify what determinism amounts to as follows. Let us assume that $\mathrm{L}$ is the proposition that fully describes the laws of nature and let us also assume that there are "gigantic" undated propositions that fully describe a possible state of the world, world propositions, in Prior's (1967) terminology. Then, determinism asserts that, for any times $t$ and $t$ ' such that $t$ ' comes after $t$, the world propositions $\mathrm{W}$ and $\mathrm{W}$ ' that truly describe the state of the world at $\mathrm{t}$ and $\mathrm{t}^{\prime}$, respectively, are such that @(t, W) and L jointly entail @(t', W').
}

Manuscrito - Rev. Int. Fil. Campinas, v. 39, n. 4, pp. 225-254, out.-dez. 2016. 


\subsection{Prefixation and Eternalism}

And now we come to the point that is most crucial for our discussion: even without determinism, once we accept eternalism, we are bound to deny the thesis of the open future. In contrast, as it is to be expected, presentism is compatible with the open future. This point can be articulated in terms of truthmakers as follows. ${ }^{21}$ Consider a dated proposition @ $(t, P)$, with P atomic, i.e a proposition of the sort that can be made true by an appropriate event, such as the proposition that on August 21, 2017 at noon John is kissing Mary. Given eternalism, all past and future events are real just as much as the present ones. Hence, even if $\mathrm{t}$ is not the present moment, there are nevertheless all the events of time t. Among them, either there is, or there isn't, an event p that works as truthmaker of @ $(t, P)$. Suppose there is. This event $\mathrm{p}$ is part of reality tout court and it is thus real from the point of view of $t$ just as much as it is real from the point of view of any previous moment t'. Hence, p can be considered not only a truthmaker for @ $(t, P)$, but also a truthmaker for @(t',@(t, P)). And clearly, if @(t',@(t, P)) has a truthmaker, then it is true, which means that @ $(t, P)$ is prefixed at t'. Suppose on the other hand that, among all the events of time $t$, there isn't a truthmaker for@(t, P). In facing this case, we may either follow truthmaker maximalism and take@(t, P) to have somehow a truthmaker, or minimize the postulation of truhmakers, while still granting that the truth @ $(t, \sim P)$ supervenes on being, or is grounded on reality (MacBride 2016). If the former, we could, for example, follow Armstrong (2004, pp. 56-59) and admit that the events of $\mathrm{t}$ constitute a totality which, by lacking a truthmaker for @ $(t, P)$, functions as truthmaker for @ $(t, \sim P)$. But then we should also admit that this totality is real from the point of view of $t$ just as much as it is real from the point of view of $t^{\prime}$, and thus is also a truthmaker for @ $\left(t^{\prime}, @(t\right.$, P)). Now, if @(t', @(t, P) has a truthmaker, then it is true, which means that @ $(t, \sim P)$ is prefixed. On the other hand, if we wish to avoid truthmaker maximalism, we should at least say that the events of time $t$, by failing to encompass a truthmaker for @ $(t, P)$, make it the case that the truth of @ $(t$,

${ }^{21}$ What I argue for here is in line with what Diekemper (2007) says in relation to what he calls "ontological fatalism."

Manuscrito - Rev. Int. Fil. Campinas, v. 39, n. 4, pp. 225-254, out.-der. 2016. 
$\sim \mathrm{P})$ supervenes on them. However, just like the Armstrongian totality, these events are real from the point of view of $\mathrm{t}$ just as much as they are real from the point of view of $\mathrm{t}^{\prime}$. Hence, the truth of $@\left(\mathrm{t}^{\prime}, @(\mathrm{t}, \sim \mathrm{P})\right)$ can also be taken to supervene on them and the prefixation of @(t, P) should again be granted. In sum, given eternalism, for any proposition $\mathrm{P}$ that can be made true by an appropriate event, i.e. an atomic proposition, and any time $t$, either it is the case that the proposition $@(t, P)$ is prefixed, or it is the case that the proposition@(t, P ) is prefixed. And of course, if we grant that the truth of all other, molecular, propositions is ultimately grounded on the truth of such propositions, we can generalize this result to all dated propositions.

It is instructive to compare eternalism and presentism at this juncture. The only events acknowledged in the presentist's ontological inventory are those of the present moment. Thus, if we consider the proposition@(t, P), where $t$ is a future moment, we can hardly find in this inventory an event that counts as truthmaker for this proposition. Nor can we find other events, which, by virtue of lacking such an event, constitute a totality that counts as truthmaker of @ $(\mathrm{t}, \sim \mathrm{P})$, or at least are such that the truth of @ $(\mathrm{t}$, $\sim \mathrm{P})$ supervenes on them. In other words, neither @ $(\mathrm{t}, \mathrm{P})$ nor $@(\mathrm{t}, \sim \mathrm{P})$ has a truthmaker, or is such that its truth supervenes on being. This is so, on the assumption that there are no other reasons granting that one of them has a truthmaker or at least that its truth is grounded on reality; for instance, if the laws of nature and the present state of the world jointly necessitated @ $(t, P)$, then we should grant that such laws and the present state of the world jointly constitute a truthmaker for @ $(t, P)$, or at least ground its truth on reality. In this case, @(t, P) should be considered true now. On the other hand, if neither@(t, P) nor @(t, P) has a truthmaker, or has its truth grounded on reality, it may be tempting, as noted above, to attribute to both of them a third truth value, or deny that they have a truth value. However, if we follow this road, we abandon classical logic, and it does not seem to me that this price is necessary in this case. I think it is better to say that both $@(t, P)$ and @(t, P) are now false, and add that one of them will be true, depending on which events will come to exist at time t; the A-theorist can, I

Manuscrito - Rev. Int. Fil. Campinas, v. 39, n. 4, pp. 225- 254, out.-dez. 2016. 
think, allow for alethic change, change of truth value over time, of propositions such as @ $(\mathrm{t}, \mathrm{P})$ and $@(\mathrm{t}, \sim \mathrm{P}) .22$

\subsection{Open Future and Libertarian Free Will}

In \$3.2 I tried to clarify the basic intuition that prefixation is a kind of necessity, by distinguishing it from other sorts of necessity, which can ground prefixation, but are not the only reasons for which there can be prefixation. I have then argued in $\$ 3.3$ that, in contrast with presentism, eternalism implies that the future is prefixed. Thus, we may say, eternalism brings about prefixation necessity directly, rather than via some other sort of necessity. In sum, in some sense, for the eternalist the future is necessary, whereas this is not so for the presentist. Let us now see which implications all this has for free will and for how presentists and eternalists may look at the future from an existential point of view.

Traditionally, with "compatibilism" and "libertarianism" we refer, respectively, to the doctrine according to which free will is compatible with the necessity imposed by determinism and thus with nomic necessity, and to the opposite view that denies this compatibility (see Kane 2002). We may call nomic compatibilism this traditional form of compatibilism, according to which an agent can be considered free despite determinism; free, in other words, even though, when she is supposedly willing freely, she could not have willed otherwise, given the laws of nature and the preceding state of the world. Correspondingly, we may say, there is nomic libertarianism, that is the view that requires the untruth of determinism for there to be free will; when an agent allegedly wills freely, she could have willed otherwise, from the point of view of nomic necessity. In other words, her willing so and so is not nomically necessary. ${ }^{23}$ Analogously, for any kind of necessity, we can

\footnotetext{
22 The approach suggested here is in line with the Peircean account of future contingents defended by Prior (1967, p. 128 ff.). In this view one cannot hold that $\mathrm{P}$ entails that it will be the case that it was the case that P (see Øhrstrøm, Peter and Hasle 2015, \4 4.2 for a discussion).

${ }^{23}$ Typically, the libertarian claims that an agent who freely does A, could have done otherwise. However, as well explained by Lowe (2008; see in particular p. 173 and p. 196), the freedom on which the libertarian insists has to do in the first place with
}

Manuscrito - Rev. Int. Fil. Campinas, v. 39, n. 4, pp. 225-254, out.-dez. 2016. 
have corresponding compatibilist and libertartian doctrines. If there is metaphysical and logical necessity, we can have metaphysical and logical compatibilism and, on the other side of the trench, metaphysical and logical libertarianism. Clearly, the eternalist can be a libertarian in a nomic, metaphysical and logical sense, since she can coherently deny that all events, and in particular willing events, are nomically, metaphysically or logically necessary. We could also consider, if you wish, theological necessity, i.e. necessity due to the will of God and add that the eternalist can of course coherently deny that all events, and specifically willing events, are theologically necessary, and thus be a theological libertarian.

But there is also, we have seen, prefixation necessity, and from the point of view of this sort of necessity the eternalist is bound to say that all events are necessary (except events at the first moment of time, if there is such a thing). Thus, the eternalist cannot embrace prefixation libertarianism. At most, from the point of view of prefixation necessity, she can be a compatibilist. Let us consider a concrete example. In Italy in 1860, while the king of Piedmont Vittorio Emanuele II was working on unifying the whole of Italy under his own crown, Giuseppe Garibaldi with a small independent army conquered the southern part of Italy that was then an independent state ruled by the king of Naples. Vittorio Emanuele II then expected that Garibaldi would offer him the newly conquered lands; the two of them thus met in the small town of Teano on October 26, 1860 at 8:30 a.m. (Italian time) and allegedly, and so we shall grant, Garibaldi famously said to the king: "I obey." Thus, let us assume, at a certain precise time t shortly after October 26, 1860 at 8:30 a.m., Garibaldi freely willed to say "I obey" and consequently, immediately afterwards, he indeed said that. If this is so, according to the libertarian conception of free will, Garibaldi at time t could have willed otherwise, i.e., he could have rather willed to say something else, or maybe he could have willed to remain silent. In sum, if at time t Garibaldi freely willed to say "I obey," then it was possible at time $t$ that at time $t$ Garibaldi did not will to say "I obey," and consequently it was not necessary at time $t$ that at time $t$ Garibaldi willed to say "I obey." And conversely, if it

the agent's volitions, or acts of will, rather than with the effects of these volitions. Thus, I think it is better to say that the libertarian conception requires that an agent who freely wills something could have willed otherwise.

Manuscrito - Rev. Int. Fil. Campinas, v. 39, n. 4, pp. 225-254, out.-dez. 2016. 
was necessary at time $t$ that Garibaldi at time t willed to say "I obey," then at t Garibaldi did not freely will to say "I obey." However, if eternalism is true, there is a sense in which it was necessary at time $t$ that Garibaldi at time $t$ willed to say "I obey." This is because it was prefixed, already fixed at a time before $t$, indeed at any time before $t$, that at time $t$ Garibaldi would have willed to say "I obey."

In sum, in an eternalist world, there is a sense in which we do not really choose anything. It may well be true that your willing $A$ at a time $t$ is not logically, metaphysically, nomically or theologically necessary, and it may well be true that this willing causes $\mathrm{A}$ to occur, so that you bring about A immediately after, at t', and accordingly you should be considered responsible for it. Yet, both your willing $A$ at $t$ and A's subsequent occurrence at t' were both prefixed and thus in some sense necessary. $A$ is not really created by you or by your willing A. You brought about A at most only in the sense that there is somehow a causal link between your willing A and the subsequent occurrence of A. But it is a link between two equally existing entities, which are equally part of reality just like various snapshots are parts of a film strip. A snapshot in a film does not bring to existence the next snapshot, it merely precedes it. Similarly, your willing A at t does not bring A to existence. A, one may say, does not exist at $t$; it rather exists at t'. But this is sufficient to say that A exists tout court, it is part of reality and thus it is not really created by you. In a sense then the existence of A was not really chosen by you. If A is part of reality tout court, then only if, per impossible, you had created the whole of temporal reality from an atemporal vantage point, you could be said to have chosen (inter alia) A.

Viewing our decisions, and more generally the future, in this way may have, I think, a significant existential impact. It may be appeasing to those who find it hard to take decisions and tend to be afraid that they will later regret their present deliberations; the thought that whatever will follow from their choices was inexorable after all may perhaps alleviate the burden they have to sustain in decision making. The other side of the coin, however, is that embracing this existential stance may detract from the image of ourselves as free agents capable of partly shaping the future and taking responsibility for this. As we have seen, eternalism leaves room for many senses in which the future is not necessary; yet the remaining unavoidable sense in which an eternalist future is necessary may leave us with a negative

Manuscrito - Rev. Int. Fil. Campinas, v. 39, n. 4, pp. 225-254, out.-dez. 2016. 
sentiment. We may feel diminished at the thought that we do not really contribute to create the future, since it is already given, and our sense of responsibility may decrease. Our pride or shame, as the case may be, for our deeds may be impoverished and inaction may be favored, as opposed to a brave desire to always live and act in such a way as to make this world a better world. If the world is all given, past, present and future, sub specie aeternitatis, this existential attitude may appear meaningless. On the contrary, in a presentist world, with its open and empty future, this attitude is perfectly justified and we can fully view ourselves as free agents, responsible for whatever deeds we bring to their existence.

\section{Conclusion}

Belief in an eternalist world, with no real becoming and thus no real ceasing to be and no real coming to be, may contribute on the one hand to tame our fear of death and to ground our desire to see as preserved what we value most; and, on the other hand, may contribute to discipline any Kierkegaardian anxiety that might seize us in deliberation. Nevertheless, the loving consideration of all positive aspects of our lives and of the world surrounding us, might, indeed should, be overwhelmed by an appropriately dismayed consideration of past sorrow, in particular sorrow of gigantic magnitude, which we know has infected this world. And this should lead, I think, to an emotional preference, perhaps even a moral preference, for a presentist world. Moreover, to the extent that we cherish a vision of ourselves as free agents capable of at least partially shaping the future with our own choices, hopefully contributing to make the world a better world, we could emotionally be driven away from an eternalist world and prefer a presentist one. For although in an eternalist world there can be libertarian free will in several senses, there remains an unavoidable residual sense in which there cannot be this sort of free will. It has been argued that libertarian free will is a precondition for morality. If this is so, one might perhaps even venture to claim that the preference for a presentist world should also be a moral preference: the world ought to be presentist to make room in it for morality in its fullest sense.

Manuscrito - Rev. Int. Fil. Campinas, v. 39, n. 4, pp. 225- 254, out.-dez. 2016. 
To the extent that the preference for an eternalist or presentist world is purely emotional, the above considerations may hopefully contribute to a better awareness of the existential stance that we associate with the theoretical choice of a temporal ontology. Or perhaps they might even shape this stance in different ways or influence the theoretical choice, at least if the grounds for a theoretical choice do not appear solid enough. Thus, I would like to hold that, at least for some of those who see the presentism vs. eternalism dispute as tangled in a theoretical stalemate, the arguments I have presented could favor the endorsement of presentism or at least the hope that presentism be true. Of course, if these arguments could be taken to lead not only to an emotional preference, but also to a moral preference for presentism, the wish that they could favor the endorsement of presentism is even more justified.

Leaving aside individual reactions and choices, does any of this have any bearing from a more objective point of view on the issue of whether the world is presentist or eternalist? Well, at least to the extent that we can characterize the preference for one doctrine over the other as moral, the question then has to do with whether we can move from ought to is, in the way suggested by Kant in the second Critique. We are then in a notoriously muddy and controversial territory, but let me nevertheless advance some ruminations. In short, I have argued, at least tentatively, that a presentist world is morally preferable to an eternalist world, because the former eschews the intolerable reality of past sorrow and leaves more room for free will, whereas the latter must acknowledge such reality and a more limited free will. If this is correct, we should at least admit that the world is presentist, given a theological perspective that has room for an omnipotent and benevolent God, since the problem of reconciling such a God with the existence of evil is, it seems to me, much more serious in an eternalist world. For in that world all past sorrow is part of reality, whereas in a presentist world at least past sorrow is out of reality, and it seems that a benevolent God should prefer this. Moreover, one could surmise that, if there is this benevolent God, the world will at some point become pure, i.e., devoid of sorrow and replete with joy. Yet, this is really possible only in a presentist world, in which past sorrow is not part of reality. For in an eternalist world one can at best hope for purity from some point onward of the temporal slices of reality lying ahead of us, which however must coexist with the

Manuscrito - Rev. Int. Fil. Campinas, v. 39, n. 4, pp. 225- 254, out.-dez. 2016. 
impure slices containing all the sorrowful events of our past. Hence, even from this extremely optimistic perspective, an eternalist world must be, as a whole, an impure world. Finally, it should be noted that the benevolent and omnipotent God, at least according to tradition, should endow us with free will in the fullest sense, and we saw that this is really possible only in a presentist world. In short, we may say that, if God exists, God must have created a presentist world and thus the world is presentist. If one does not embrace a theological perspective, there is still room to move from ought to $i s$, if one is willing to attribute ontological efficacy to values, in the way suggested by Leslie (see, e.g., Leslie 2013 and references therein). From this standpoint, one could still argue that, if presentism is morally preferable to eternalism for the reasons presented above, then it ought to be true and thus, given the intrinsic efficacy of values, it is true.

As one can see, and as it was to be expected, so many problematic assumptions are needed to jump from the moral preferability of presentism to its truth that one can hardly hope to establish it simply on this basis. Nevertheless, I hope to have shown that there are good reasons to say that we should at least wish that presentism be true. ${ }^{24}$

\section{References}

Armstrong, D. M. Truth and Truth-makers, Cambridge University Press, Cambridge, 2004.

BARnes, E. and CAmeron, R. "The Open Future: Bivalence, Determinism and Ontology," Philosophical Studies, 146, pp. 291-309, 2009. and Cameron, R. "Back to the Open Future," Philosophical Perspectives, 25, pp. 1-26, 2011.

\footnotetext{
${ }^{24}$ I wish to thank for their valuable comments or discussions on the topics of this paper Emiliano Boccardi, Ernesto Graziani, Tomis Kapitan, Greg Landini, Nathan Oaklander, Michele Paolini Paoletti, Gianluigi Oliveri, Gianni Rigamonti and an anonymous referee. Tomis passed away shortly after the completion of this paper and I wish to dedicate it to his memory.
}

Manuscrito - Rev. Int. Fil. Campinas, v. 39, n. 4, pp. 225- 254, out.-dez. 2016. 
Bigelow, J. "Presentism and Properties," Philosophical Perspectives, 10, pp. 35-52, 1996.

Bourne, C. A Future for Presentism, Oxford University Press, Oxford, 2006.

Campbell J. K, M. O'Rourke, and H. Silverstein (eds.), Time and Identity, The Mit Press, Cambridge, pp. 49-77, 2010.

CRISP, T. "Presentism and the Grounding Objection," Noûs, 41, pp. 90-109, 2007.

DieKeMPER, J. "B-Theory, Fixity and Fatalism,” Noûs, 41, pp. 429-452, 2007.

Dorato, M. Time and reality, CLUEB, Bologna, 1995.

Einstein, A. and Besso, M. Correspondence, 1903-1955, ed. by P. Speziali, Hermann, Paris, 1972.

HAAPARANTA, L., HINTIKKA, J. Frege Synthesized. Dordrecht: Reidel Publishing Co., 1986.

Gale, R. (ed.) The Philosophy of Time, Humanities Press, New Jersey, 1968.

Goldschmidt T. (ed.), The Puzzle of Existence. Why there is Something Rather than Nothing? , pp. 128-143, Routledge, London, 2013.

Kane, R. (ed.) The Oxford Handbook of Free Will, Oxford University Press, Oxford, 2002.

KeLLER, S. "Presentism and Truthmaking," in D. W. Zimmerman (ed.), Oxford Studies in Metaphysics, Volume I, Oxford University Press, Oxford, pp. 83-104, 2004.

LESLIE, J. “A Proof of God's Reality,” in T. Goldschmidt (ed.)(2013), pp. 128-143.

LOMBARD, L. B. "Time for a Change: A Polemic against the Presentism-Eternalism Debate," in J. K Campbell, M. O'Rourke, and H. Silverstein (eds.) (2010), pp. 49-77.

Lowe, E. J. Personal Agency, Oxford University Press, Oxford, 2008.

MACBRIDE, F., "Truthmakers," The Stanford Encyclopedia of Philosophy (Fall 2016 Edition), E. N. Zalta (ed.), URL = $<$ http://plato.stanford.edu/archives/fall2016/entries/truthmakers/>.

Merricks, T. Truth and Ontology, Oxford University Press, Oxford, 2007.

OAKLander, L. N. "Freedom and the New Theory of Time," in R. Le Poidevin (ed.) (1998), pp. 185-205.

Manuscrito - Rev. Int. Fil. Campinas, v. 39, n. 4, pp. 225-254, out.-dez. 2016. 
"Dolev's Anti-Metaphysical Realism: A Critique," in L. N. Oaklander (ed.) (2014), pp. 3-29.

(ed.) (2014), Debates in the Metaphysics of Time, Bloomsbury, London, pp. 329.

"Temporal Phenomena, Ontology and the R-theory," Metaphysica, 16, 253269, 2015.

Orilia, F. "Two Metaphysical Perspectives on the Duration of the Present," in L. N. Oaklander (ed.) (2014), pp. 51-70.

"The Moral Desirability of Presentism," presented at the Conference God, Time, Infinity, International Center for Formal Ontology, Warsaw, 22-24 September 2015, forthcoming in M. Szatkowski (ed.), God, Time, Infinity, De Gruyter, Berlin.

“Moderate Presentism,” Philosophical Studies, 173, pp. 589-607, 2016.

Øhrstrøm, P. and Hasle, P. "Future Contingents," in E. Zalta (ed.) (2015), The Stanford Encyclopedia of Philosophy.

<http://plato.stanford.edu/archives/win2015/entries/future-contingents>.

R. LE PoIDEvin (ed.) (1998), Questions of Time and Tense, Clarendon Press, Oxford, pp. 185-205.

Prior, A.N. Past, Present and Future, Clarendon Press, Oxford, 1967.

ReICHEnBACH, H. The Direction of Time, University of California Press, Berkeley, 1956.

RusselL, B. Mysticism and Logic and Other Essays, G. Allen \&Unwin, London, 1917.

SEVERINO, E. La struttura originaria, La Scuola, Brescia, 1958.

VAN FraAssen, B. “Singular Terms, Truth-Value Gaps, and Free Logic,” Journal of Philosophy, 63, pp. 481-495, 1966.

VAN HEIJENOORT, J. "Frege on Vagueness". In L. Haaparanta and J. Hintikka (eds.) (1986), pp. 31-45.

Zimmerman D. W. (ed.) Oxford Studies in Metaphysics, Volume I, Oxford University Press, Oxford, pp. 83-104, 2004.

Manuscrito - Rev. Int. Fil. Campinas, v. 39, n. 4, pp. 225- 254, out.-dez. 2016. 